\title{
Insiden dan Faktor-Faktor yang Berhubungan dengan Sepsis Neonatus di RSUP Sanglah Denpasar
}

\author{
Putu Junara Putra \\ Bagian/SMF Ilmu Kesehatan Anak, Fakultas Kedokteran Universitas Udayana/RSUP Sanglah, Denpasar
}

\begin{abstract}
Latar belakang. Sepsis neonatus sampai saat ini masih merupakan masalah utama di bidang pelayanan dan perawatan neonatus. Insiden sepsis neonatus bervariasi dari 1 sampai 4 dari 1000 kelahiran hidup di negara maju dan 10 sampai 50 dalam 1000 kelahiran hidup di negara berkembang. Kematian pada sepsis neonatus masih tinggi, terutama di negara-negara berkembang.

Tujuan. Menggambarkan insiden, angka kematian, dan faktor yang terkait dengan kematian pada sepsis neonatus di RSUP Sanglah, Denpasar.

Metode. Penelitian retrospektif dilakukan di Ruang Rawat Neonatologi Bagian Ilmu Kesehatan Anak, RSUP Sanglah, Denpasar dari Januari hingga Desember 2010. Seratus dua puluh lima pasien dengan sepsis neonatus dilibatkan dalam penelitian. Analisis univariat dengan kai kuadrat, analisis multivariat dengan regresi logistik, dan nilai $\mathbf{p}<0,05$ dianggap bermakna.

Hasil. Terdapat 125 kasus sepsis neonatus yang diteliti dengan gambaran 56,8\% dari subjek laki-laki, $72 \%$ lahir secara spontan, $64,0 \%$ lahir dengan asfiksia, $56 \%$ berat lahir rendah, $68,8 \%$ prematur, dan $86,4 \%$ dengan sepsis neonatus awitan dini (SNAD). Insiden sepsis neonatus 5\%, dengan tingkat kematian 30,4\%. Berat lahir rendah dan prematuritas secara bermakna berkaitan dengan kematian pada sepsis neonatus (RR 2,66, 95\% IK 1,03-6,90), $p=0,04$ dan RR 5, 45 (95\% IK 4,47-20,25), p=0,01).

Kesimpulan. Insiden sepsis neonatus di RSUP Sanglah, Denpasar 5\% dengan tingkat kematian $30,4 \%$. Berat lahir rendah dan prematuritas terkait dengan kematian pada sepsis neonatus. Sari Pediatri 2012;14(3):205-10.
\end{abstract}

Kata kunci: sepsis neonatus, kematian, faktor risiko

\section{Alamat korespondensi:}

Dr. Putu Junara Putra, SpA. Bagian Ilmu Kesehatan Anak FK Unud/RSUP Sanglah, Denpasar. Jl. P. Nias, Denpasar Bali.Telp/fax: 0361-244038. Email:perinatology@yahoo.com

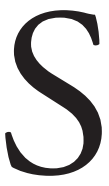

epsis neonatus sampai saat ini masih merupakan masalah utama di bidang pelayanan dan perawatan neonatus. World Health Organization (WHO) memperkirakan, terdapat 5 juta kematian neonatus setiap tahun dengan angka kematian neonatus (kematian dalam 28 hari pertama kehidupan) adalah 34 per 1000 kelahiran hidup, dengan 98\% kematian tersebut berasal dari negara berkembang. ${ }^{1}$ 
Angka kematian neonatus di Asia Tenggara adalah 39 per 1000 kelahiran hidup. ${ }^{2}$ Laporan $\mathrm{WHO}$ yang dikutip dari State of the world's mother 2007 (data tahun 20002003) dikemukakan bahwa $36 \%$ kematian neonatus disebabkan oleh penyakit infeksi, di antaranya sepsis, pneumonia, tetanus, dan diare. Dua puluh tiga persen disebabkan asfiksia, 7\% kelainan bawaan, 27\% bayi kurang bulan dan berat lahir rendah, serta $7 \%$ sebab lain. ${ }^{3}$ Sepsis neonatus sebagai salah satu bentuk penyakit infeksi pada bayi baru lahir masih merupakan masalah utama yang belum terpecahkan sampai saat ini. Insiden sepsis neonatus bervariasi 1 sampai 4 dari 1000 kelahiran hidup di negara maju dan 10 sampai 50 dari 1000 kelahiran hidup di negara berkembang. ${ }^{2,3}$ World Health Organization juga melaporkan case fatality rate yang tinggi (40\%) pada kasus sepsis neonates. Hal tersebut terjadi karena banyak faktor risiko infeksi pada masa perinatal yang belum dapat dicegah dan ditanggulangi, ${ }^{4}$ dan angka kematian bayi dapat mencapai $50 \%$ apabila tata laksana tidak dilakukan dengan baik. ${ }^{4-6}$

Di negara berkembang, kematian bayi karena sepsis neonatus sekitar 34 per 1000 kelahiran hidup, yang terjadi terutama di minggu pertama kehidupan, sementara di negara maju 5 per 1000 kelahiran hidup. ${ }^{7}$ Di Malaysia, insiden sepsis neonatus 5\%-10\% dan angka kematian 23\%-50\%. Di rumah sakit Cipto Mangunkusumo Jakarta, Januari sampai September 2005, didapatkan insiden sepsis neonatus 13,68\% dari semua kelahiran hidup dengan angka kematian $14,18 \% .{ }^{8}$ Di rumah sakit Sanglah, ditemukan dari Januari 2003 sampai dengan Desember 2004 insiden sepsis neonatus 5,3\% dengan tingkat kematian $56 \%$.

Penelitian kami bertujuan untuk mengetahui insiden dan untuk mengidentifikasi faktor-faktor (jenis kelamin, cara persalinan, asfiksia, usia kehamilan, berat lahir, onset sepsis) yang berkaitan dengan kematian akibat sepsis neonatus di RSUP Sanglah. Hasil penelitian kami harapkan dapat digunakan dalam menyusun strategi pencegahan yang akan mengurangi kesakitan dan kematian.

\section{Metode}

Penelitian retrospektif di Ruang Rawat Neonatologi RSUP Sanglah dari 1 Januari 2010 sampai dengan 31 Desember 2010. Kriteria inklusi adalah semua bayi dengan sepsis neonatus. Kriteria eksklusi adalah rekam medis yang tidak lengkap dan pulang atas permintaan sendiri. Data karakteristik pasien mencakup jenis kelamin, cara persalinan, kondisi pada saat kelahiran, usia kehamilan, berat lahir, dan jenis sepsis. Hasil merupakan keadaan bayi saat keluar dari rumah sakit, dikelompokkan dalam dua bagian yaitu hidup dan meninggal. Semua bayi yang lahir di RSUP Sanglah dicatat datanya sejak kelahiran, sedangkan pasien rujukan dicatat datanya sejak masuk RSUP Sanglah.

Sepsis neonatus adalah suatu sindrom klinis yang disertai dengan bakteremia yang terjadi selama bulan pertama kehidupan. Dalam penelitian kami, sepsis didiagnosis berdasarkan gejala klinis dan biakan darah yang positif. Sepsis diklasifikasikan ke sepsis neonatus awitan dini (SNAD) jika mulai terjadi $<72$ jam kehidupan dan sepsis neonatus awitan lambat (SNAL) jika terjadi $>72$ jam kehidupan. Faktor risiko penyebab kematian adalah cara persalinan yang dikelompokkan menjadi spontan atau tidak spontan, kondisi pada saat lahir yang dikelompokkan menjadi asfiksia, jika bayi tidak segera menangis dengan skor Apgar $<7$ pada 1 menit pertama, dan vigorous jika bayi menangis segera dengan skor Apgar $\geq 7$ di 1 menit pertama, berat lahir bayi diukur dalam waktu 1 jam setelah lahir dan dikelompokkan ke dalam $<2500$ gram dan $\geq 2500$ gram, usia kehamilan saat lahir, ditentukan berdasarkan hari pertama periode menstruasi terakhir atau dengan menggunakan New Ballard Score (NBS), dikelompokkan menjadi prematur dan cukup bulan. Jenis kelamin dikelompokkan menjadi laki-laki dan perempuan.

Besar sampel dihitung dengan menggunakan risiko relatif $1,5, \alpha=5 \%, \beta=10 \%$ dan proporsi dari faktor risiko $28 \%$. Menurut rumus di atas, subjek penelitian minimal adalah 96 pasien.

Karakteristik subjek disajikan secara deskriptif. Uji perbedaan antara kelompok menggunakan $X^{2}$ dan analisis multivariat untuk mengetahui faktor risiko yang bermakna menggunakan regresi logistik. Nilai $\mathrm{p}<0,05$ dengan interval kepercayaan 95\% dianggap bermakna secara statistik. Penelitian telah disetujui oleh komite etik Fakultas Kedokteran Universitas Udayana / RSUP Sanglah, Denpasar.

\section{Hasil}

Di antara 3012 neonatus yang dirawat di RSUP Sanglah, didapatkan 152 bayi mengalami sepsis neonatus. Dua puluh tujuh neonatus dieksklusi, 19 neonatus karena menolak anjuran medis dan 8 
neonatus karena rekam medis tidak lengkap. Seratus duapuluh lima bayi dengan sepsis neonatus dilibatkan dalam penelitian ini. Insiden sepsis neonatus adalah $5 \%$.

Berdasarkan data karakteristik dasar, sebagian besar ibu berusia antara $18-35$ tahun $(87,2 \%)$ dan pendidikan

Tabel 1.Karakteristik sepsis neonatus

\begin{tabular}{lcc}
\hline Karakteristik & $\begin{array}{c}\text { Mati } \\
(\mathrm{n}=38)\end{array}$ & $\begin{array}{c}\text { Hidup } \\
(\mathrm{n}=87)\end{array}$ \\
\hline $\begin{array}{l}\text { Usia ibu (tahun) } \\
\leq 18\end{array}$ & $2(5,3)$ & $4(4,6)$ \\
$>18-35$ & $31(81,6)$ & $78(89,7)$ \\
$\quad>35$ & $5(13,2)$ & $5(5,7)$ \\
Pendidikan ibu & & \\
$\quad$ Universitas & $3(7,9)$ & $7(8,0)$ \\
SMA & $16(42,1)$ & $39(44,8)$ \\
SMP & $7(18,4)$ & $21(24,1)$ \\
SD & $12(31,6)$ & $20(23)$ \\
Kehamilan ke- & & \\
1 & $18(47,4)$ & $48(55,2)$ \\
2 & $10(26,3)$ & $28(32,2)$ \\
$\geq 3$ & $10(26,3)$ & $11(12,6)$ \\
Pemeriksaan kehamilan & & \\
$\quad \geq 3$ & $32(84,2)$ & $83(95,4)$ \\
$<3$ & $6(15,8)$ & $4(4,6)$ \\
\hline
\end{tabular}

sekolah menengah atas (SMA) merupakan jumlah terbanyak $(44,0 \%)$. Kehamilan pertama merupakan jumlah terbanyak $(52,8 \%)$, dan pemeriksaan kehamilan $>3 x$ selama hamil $92,0 \%$.

Berdasarkan faktor risiko untuk kematian pada sepsis neonatus kami menemukan sebagian besar kasus sepsis neonatus terjadi pada laki-laki $(56,8 \%)$, lahir spontan (72\%), dan asfiksia (64\%). Sebagian besar subjek prematur $(68,8 \%)$ dan $56 \%$ subjek memiliki berat lahir rendah (<2500 gram) (Tabel 2). Dari 125 bayi dengan sepsis neonatus, sebagian besar kasus $(86,4 \%)$ SNAD. Tingkat kematian dari sepsis neonatal $30,4 \%$. Angka kematian sepsis neonatus berhubungan dengan berat lahir rendah dan usia kehamilan $(p=0,001$ dan $p<0,001$ ) (Tabel 2).

Hasil analisis multivariat menunjukkan bahwa prematuritas dan berat lahir rendah merupakan faktor yang berpengaruh terhadap kematian sepsis neonatus (Tabel 3).

Tabel 3.Uji regresi logistik multivariat berdasarkan berat lahir dan umur kehamilan

\begin{tabular}{lccc}
\hline Variabel & RR & IK95\% & P \\
\hline Umur kehamilan & 5,45 & $1,47-20,25$ & 0,01 \\
Berat lahir rendah & 2,66 & $1,03-6,90$ & 0,04 \\
\hline
\end{tabular}

Tabel 2.Faktor risiko kematian sepsis neonatus

\begin{tabular}{|c|c|c|c|c|c|}
\hline \multirow[b]{2}{*}{ Variabel } & \multicolumn{2}{|c|}{ Luaran } & \multirow[b]{2}{*}{$\mathrm{RR}$} & \multirow[b]{2}{*}{$95 \% \mathrm{CI}$} & \multirow[b]{2}{*}{$\mathrm{p}$} \\
\hline & $\begin{array}{c}\text { Mati } \\
(n=38)\end{array}$ & $\begin{array}{l}\text { Hidup } \\
(\mathrm{n}=87)\end{array}$ & & & \\
\hline \multicolumn{6}{|l|}{ Jenis kelamin } \\
\hline Laki-laki & 22 & 49 & 1,07 & $0,49-2,31$ & 0,87 \\
\hline Perempuan & 16 & 38 & & & \\
\hline \multicolumn{6}{|l|}{ Cara persalinan } \\
\hline Spontan & 30 & 60 & 1,69 & $0,68-4,16$ & 0,25 \\
\hline Tidak spontan & 8 & 27 & & & \\
\hline \multicolumn{6}{|l|}{ Asfiksia : } \\
\hline $\mathrm{Ya}$ & 21 & 59 & 0,59 & $0,27-1,28$ & 0,18 \\
\hline Tidak & 17 & 28 & & & \\
\hline \multicolumn{6}{|l|}{ Umur kehamilan } \\
\hline Prematur & 35 & 51 & 8,24 & $2,35-28,86$ & $<0,001$ \\
\hline Aterm & 3 & 36 & & & \\
\hline \multicolumn{6}{|l|}{ Berat lahir (gram) } \\
\hline$<2500$ & 30 & 40 & 4,41 & $1,82-10,69$ & 0,001 \\
\hline$\geq 2500$ & 8 & 47 & & & \\
\hline \multicolumn{6}{|l|}{ Klasifikasi sepsis } \\
\hline Sepsis neonatus awitan dini & 35 & 73 & 2,24 & $0,60-8,30$ & 0,22 \\
\hline Sepsis neonatus awitan lambat & 3 & 14 & & & \\
\hline
\end{tabular}




\section{Pembahaan}

Di negara berkembang, sepsis neonatus tetap merupakan penyebab utama kematian dan kesakitan meskipun sudah ada kemajuan terbaru dalam teknologi dan terapi. Beberapa faktor yang bertanggung jawab untuk terjadia sepsis, antara lain sistem kekebalan tubuh bayi yang baru lahir belum matang, penurunan sel darah putih fagositik, penurunan produksi sitokin, dan lemahnya kekebalan humoral. ${ }^{10-12}$ Berbagai faktor ibu, janin, dan lingkungan juga berkontribusi terhadap sepsis pada neonatus. Beberapa dari faktor ibu antara lain ketuban pecah dini, demam ibu dalam 2 minggu sebelum persalinan, ketuban dengan mekonium, cairan amnion yang berbau dan alat-alat yang digunakan untuk persalinan. Faktor janin meliputi berat lahir, usia kehamilan, dan skor Apgar. ${ }^{8} 13$

Kami menemukan insiden sepsis neonatus 5\%. Insiden sepsis neonatus bervariasi antara ruang perawatan bayi yang satu dengan yang lainnya dan bervariasi pula dalam ruang perawatan bayi yang sama pada waktu yang berbeda. Sebuah penelitian kohort di Israel, menjelaskan bahwa 2,4\% dari 15.839 bayi mengalami SNAD. Penelitian Stoll ${ }^{14}$ melaporkan secara umum insiden dari sepsis neonatus adalah 5-6 per 1000 kelahiran hidup di Asia Selatan dan Asia Tenggara, 6-21 per 1000 kelahiran hidup di sub-Sahara Afrika, dan 1,8-12 per 1000 kelahiran hidup pada Timur Tengah dan Afrika Utara, serta 2,9 per 1000 kelahiran hidup di Americas/Caribbean. Di Rumah Sakit Songklanagarin, sebuah rumah sakit rujukan tersier utama di Thailand Selatan, insiden sepsis neonatus sebesar 4,3\%. ${ }^{3}$ Insiden sepsis neonatus pada periode Desember 2006 sampai dengan Juli 2007 di rumah sakit Cipto Mangunkusumo, Jakarta dengan biakan darah positif $6,4 \% .{ }^{15}$ Perbedaan insiden mungkin karena faktor-faktor: geografis, ras, ekonomi, sosial, budaya, teknologi, fasilitas perawatan, dan dasar untuk membuat diagnosis sepsis neonatus.

Kematian sepsis neonatus dalam penelitian kami $30,4 \%$. Berbeda dengan penelitian sebelumnya, tingkat kematian sepsis neonatus di RSUP Sanglah menurun dari $56 \%$ menjadi $30,4 \%$. Kondisi tersebut mungkin disebabkan pendekatan diagnosis yang lebih baik, karena sejak 2007 digunakan pendekatan gejala klinis, faktor risiko sepsis (mayor dan minor), dan pemeriksaan penunjang sepsis. Diagnosis sepsis neonatus dengan pendekatan ini lebih akurat. Unit perawatan intensif neonatus (UPIN) di RSUP Sanglah juga berkembang, baik dari segi peralatan maupun sumber daya manusia. Laboratorium diagnostik juga berkembang dengan baik, sehingga pemeriksaan sepsis mudah dan dapat memberikan tata laksana kepada pasien dengan akurat. Kemajuan tersebut berdampak pada lebih baiknya penegakan diagnosis dan pengelolaan sepsis neonatus sehingga angka kematian karena sepsis berkurang. Angka kematian sepsis neonatus bervariasi dari satu rumah sakit ke rumah sakit lain yang serupa antar negara. Angka kematian dari sepsis neonatus di Rumah Sakit Ibu dan Anak Bashrah Irak 44,2\%, ${ }^{4}$ sedangkan tingkat kematian lebih rendah terdeteksi di Sao Paulo State University (UNESP) di Brasil yang melaporkan kematian akibat sepsis neonatus 18\%, ${ }^{16}$ dan juga di Rumah Sakit Universitas Hindia Barat, Jamaika ditemukan angka kematian karena sepsis neonatus $6,7 \% .{ }^{10}$ Kasus kematian sepsis neonatus di Teheran Iran 15, 1\%. ${ }^{17}$ Di Indonesia sendiri, RSCM Jakarta melaporkan bahwa kematian sepsis neonatus $14,18 \% .{ }^{8}$ Hasil serupa dilaporkan di Rumah Sakit Moewardi Surakarta yang menemukan bahwa angka kematian sepsis neonatus $40 \% .{ }^{18}$ Perbedaan dalam tingkat kematian pada sepsis neonatus antar negara dapat dijelaskan oleh berbagai faktor, antara lain faktor ekonomi, geografis dan sosial rasial, penggunaan ventilator, inkubator, dan mikroorganisme yang berbeda serta penggunaan antibiotik yang berbeda., ${ }^{2,4,5}$ Dalam penelitian kami, sebagian besar kasus kematian disebabkan karena neonatus yang memiliki indikasi perawatan UPIN tidak dapat dirawat, karena kapasitas yang terbatas. Neonatus tersebut dirawat di ruang rawat bayi dengan peralatan inkubator dan monitor sangat terbatas dan ventilator tidak tersedia. Hasil biakan darah yang terlambat juga dapat menjadi penyebab karena pemberian terapi kausatif menjadi terlambat.

Kami telah mengidentifikasi berat lahir rendah dan prematuritas berkaitan dengan kematian pada neonatus dengan sepsis bakteri. Hasil mirip dengan penelitian terdahulu yang dilakukan di berbagai negara berkembang dan negara maju. Jumah $\mathrm{dkk}^{4}$ menemukan bahwa faktor yang dapat memprediksi kematian sepsis neonatus adalah berat lahir rendah, prematuritas, trombositopenia, neutropenia, biakan darah positif untuk Klebsiella spp, capillary refill time yang memanjang, sklerema, dan tanda-tanda dehidrasi. Prematuritas, berat lahir sangat rendah dan jenis kelamin perempuan adalah faktor yang berkaitan dengan hasil yang buruk. ${ }^{10}$

Kaitan antara prematuritas dengan angka kematian sepsis neonatus karena kekebalan humoral dan selular yang kurang. Seperti kita ketahui mikro organisme penyebab sepsis akan memicu kaskade sepsis yang dimulai dengan pelepasan mediator inflamasi sepsis. 
Mediator inflamasi primer dilepaskan dari sel-sel akibat aktivasi makrofag. Pelepasan mediator akan mengaktivasi sistem koagulasi dan komplemen. ${ }^{19,20}$ Infeksi akan dilawan oleh tubuh, baik melalui sistem imunitas selular yang meliputi monosit, makrofag, dan neutrofil serta melalui sistem imunitas humoral dengan membentuk antibodi dan mengaktifkan jalur komplemen.

Pengenalan patogen oleh CD14 dan TLR-2 serta TLR-4 di membran monosit dan makrofag akan memicu pelepasan sitokin untuk mengaktifkan sistem imunitas selular. Pengaktifan tersebut menyebabkan sel $\mathrm{T}$ akan berdiferensiasi menjadi sel T helper-1 (Th1) dan sel T helper-2 (Th2). Sel Th1 mensekresikan sitokin proinflamasi seperti tumor nekrosis faktor (TNF), interferon $\gamma$ (IFN- $\gamma$ ), interleukin 1- $\beta$ (IL-1 $\beta$ ), IL-2, IL-6 dan IL-12. Sel Th2 mensekresikan sitokin antiinflamasi seperti IL-4, -10, dan -13. Pembentukan sitokin proinflamasi dan anti inflamasi diatur melalui mekanisme umpan balik yang kompleks. Sitokin proinflamasi terutama berperan menghasilkan sistem imun untuk melawan kuman penyebab. Akan tetapi, pembentukan sistem imun pada bayi prematur kurang sempurna sehingga bayi prematur akan lebih mudah mengalami sepsis. Antibodi ibu transplasenta yang pada awalnya menghasilkan kekebalan humoral, seperti imunoglobulin, cenderung diterima oleh bayibayi prematur tidak sebanyak pada bayi cukup bulan. Bayi prematur memiliki immunoglobulin yang sangat rendah kecuali untuk IgG spesifik terhadap antigen ibu, karena Ig secara pasif ditransfer melalui plasenta selama trimester terakhir kehamilan. ${ }^{10,11,16,21}$ Selain itu, bayi prematur memerlukan rawat inap yang lebih panjang sehingga dapat meningkatkan risiko infeksi nosokomial. ${ }^{10}$

Keterbatasan penelitian kami antara lain, penelitian retrospektif tidak memasukkan variabel lain seperti tanda dan gejala klinis, riwayat kehamilan ibu, penyakit yang diderita selama kehamilan, dan pengukuran variabel independen yang terbatas. Penelitian prospektif terhadap bayi-bayi dengan faktor risiko terkait dengan kematian sepsis neonatus sangat disarankan.

\section{Kesimpulan}

Kejadian sepsis neonatus 5,0\% dengan tingkat kematian $30,4 \%$. Berat lahir rendah dan prematur berhubungan dengan kematian akibat sepsis neonatus. Strategi untuk mengurangi angka kematian pada neonatus dengan sepsis harus mencakup langkah-langkah yang bertujuan mengurangi kejadian prematuritas dan bayi berat lahir rendah.

\section{Ucapan terimakasih}

Peneliti mengucapkan terimakasih kepada Kepala Sub Divisi Neonatologi Bag/SMF Ilmu Kesehatan Anak FK UNUD/RSUP Sanglah, Dr. I Made Kardana, Sp.A(K), peserta PPDS-I, Kepala Ruang Neonatologi, Kepala Ruang NICU beserta paramedis, dan orang tua bayi yang telah memberikan informasi, perhatian, tenaga, dan membantu penelitian ini.

\section{Daftar pustaka}

1. Aminullah A. Penatalaksanaan sepsis neonatorum. Jakarta: Departemen Kesehatan Republik Indonesia; 2007. h. 3-80.

2. Puopolo KM. Bacterial and fungal infections. Dalam: Cloherty JP, Eichenwald EC, Stark AR, penyunting. Manual of neonatal care. Edisi ke enam. Philadelphia: Lippincott William \& Wilkins; 2008. h. 274-300.

3. Janjindamai W, Petpisal S. Time to positivity on blood culture in newborn infants. Southeast As J Trop Med Public Health 2006; 37:171-5.

4. Jumah DS, Hassan MK. Predictor of mortality outcome in neonatal sepsis. The Medical Journal of Basrah University (MJBU) 2007; 25:11-8.

5. Aminullah A. Masalah terkini sepsis neonatorum. Dalam: Hegar B, Trihono PP, Ifran EB, penyunting. Update in neonatal infection. Pendidikan Kedokteran Berkelanjutan Ilmu Kesehatan Anak XLVIII, Departemen Ilmu Kesehatan Anak FK UI/RSCM Jakarta. Jakarta: Departemen ilmu kesehatan anak FKUI-RSCM; 2005.h.1-16.

6. Klein JO, Remington JS. Current concepts of infections of the fetus and newborn infant. Dalam: Remington J, Klein J, penyunting. Infectious Diseases of the Fetus and Newborn. Philadelphia: WB Saunders; 2000.h.1-24.

7. Ayoniyi DO, Udo SJ, Oguntibeju OO. An epidemiological survey of neonatal sepsis in a hospital in Western Nigeria. African J Microbiol Res 2009; 3:385-9.

8. Rohsiswatmo R. Kontroversi diagnosis sepsis neonatorum. Dalam: Hegar B, Trihono PP, Ifran EB, penyunting. Update in neonatal infection. Pendidikan Kedokteran Berkelanjutan Ilmu Kesehatan Anak XLVIII, Departemen Ilmu Kesehatan Anak FK UI/RSCM 
Jakarta. Jakarta: Departemen ilmu kesehatan anak FKUIRSCM; 2005. h. 32-43.

9. Suarca IK, Kardana M, Iswari IS, penyunting. Blood culture and sensitivity test pattern of early versus late onset sepsis in neonatal ward Sanglah Hospital Denpasar. Prosiding the $13^{\text {th }}$ National Congress of Child Health KONIKA XIII: July 4-7, 2005; Bandung, Indonesia.

10. Trotman H, Bell Y, Thame M, Nicholson AM, Barton M. Predictor of poor outcome in neonates with bacterial sepsis admitted to the University Hospital of the West Indies. West Indian Med J 2006; 55:80-4.

11. Ringer SA. Care of the extremely low birth weight infant. Dalam: Cloherty JP, Eichenwald EC, Stark AR, penyunting. Manual of Neonatal Care. Edisi ke-6. Philadelphia: Lippincott William \& Wilkins; 2008.h.78-85.

12. Shah GS, Budhathoki S, Das BK, Mandal RN. Risk factors in early neonatal sepsis. Kathmandu University Med J 2006; 4:187-91.

13. Klinger G, Levy I, Sirota L, Boyke V, Veva LL, Reichman B. Outcome of early onset sepsis in national cohort of very low birth weight infant. Pediatrics 2010; 125:736-40.

14. Stoll B. Neonatal infection: a global perspective. Dalam: Remington J, Klein J, penyunting. Infectious diseases of the fetus and newborn. Philadelphia:WB Saunders; 2000.h.139-68.
15. Juniatiningsih A, Aminullah A, Firmansyah A. Profil mikroorganisme penyebab sepsis neonatorum di Departemen Ilmu Kesehatan Anak Rumah Sakit Cipto Mangunkusumo Jakarta. Sari Pediatri 2008;10:60-5.

16. Bentlin MR, Rugolo LMSS. Late onset sepsis: epidemiology, evaluation, and outcome. NeoReviews. 2010; $11: 426-35$.

17. Torkaman M, Afharpaiman SH, Hoseini MJ, Moradi M, Mazraati A, Amirsalari S, dkk. Platelet count and neonatal sepsis: a high prevalence of Enterobacter spp. Singapore Med J 2009;50:482-5.

18. Hafidh Y, Hidayah D, Sunyataningkamto. Factors affecting mortality of neonatal sepsis in Moewardi Hospital Surakarta. Paediatr Indones 2007;47:74-7.

19. Short MA. Linking the sepsis triad of inflammation, coagulation and suppressed fibrinolysis to infants. Adv Neonat Care 2004;5:258-73.

20. Bone RC. A Continuing evolution in our understanding of the systemic inflammatory response syndromes (SIRS) and the multiple organ dysfunction syndromes (MODS). Ann Intern Med 1996;125: 80-7.

21. Edmond K, Zaidi A. New approaches to preventing, diagnosing, and treating neonatal sepsis. PLoS Medicine 2010:7:1-7. 